\title{
A MODEL FOR CONSTRUCTION OF STATURE FROM TRANS-TUBERCULAR BREADTH BY REGRESSION METHOD
}

\author{
Parul1, Monica Jain², Lovesh Shukla ${ }^{3}$ \\ ${ }^{1}$ Resident, Department of Anatomy, Maharaja Agrasen Medical College, Agroha. \\ 2 Professor, Department of Anatomy, Maharaja Agrasen Medical College, Agroha. \\ ${ }^{3}$ Senior Professor and HOD, Department of Anatomy, Maharaja Agrasen Medical College, Agroha.
}

ABSTRACT
Stature is an important tool in the field of anthropometry and is of great scientific importance in the field of Medicine.
AIMS AND OBJECTIVES
To predict stature of an individual from trans-tubercular breadth and to derive a regression equations for estimation of stature
in males and females.

\section{MATERIAL AND METHODS}

The present study was conducted on 150 male and 150 female, in the age group of 20-40 years. Stature of the subject was measured using anthropometer rod. Trans-tubercular breadth was measured with the help of spreading calliper.

\section{RESULTS}

Linear regression analysis was performed and regression equations for predicting stature from trans-tuberuclar breadth were derived. Correlation coeffcient for predicting stature from trans-tubercular breadth were 0.31 and 0.27 in males and females respectively.

\section{CONCLUSION}

This study provides an additional tool of sttaure estimation particularly in absence of other measures.

\section{KEYWORDS}

Stature, Trans-Tubercular Breadth, Anthropometer Rod, Spreading Calliper.

HOW TO CITE THIS ARTICLE: Parul, Jain M, Shukla L. A model for construction of stature from trans-tubercular breadth by regression method. J. Evolution Med. Dent. Sci. 2016;5(35):2065-2067, DOI: 10.14260/jemds/2016/484.

\begin{abstract}
INTRODUCTION
Stature estimation is an important tool in the field of anthropometry. It can be used in the calculation of basal metabolic rate, body mass index, body surface area, vital capacity and for adjustment of drug dosages. It is also of great scientific importance in the field of forensic medicine. Estimation of stature from measurements like foot length and breadth, hand length and breadth and length of long bones have extensively been studied in different populations by different authors.[1-4] but scanty literature is available for stature measurement from trans-tubercular breadth (TTB).[5] Iliac tubercle is situated approximately $5 \mathrm{~cm}$ posterosuperior to anterior superior iliac spine on iliac crest.[6] Transtubercular breadth is the distance between two tubercles of iliac crest. The present study was undertaken to estimate and evaluate possible correlation between stature of an individual and TTB in both, males and females.
\end{abstract}

\section{MATERIAL AND METHODS}

After getting permission from institutional ethical committee, the present study was conducted on 300 subjects ( 150 male and 150 female) in the age group of 20-40 year.

Financial or Other, Competing Interest: None.

Submission 14-03-2016, Peer Review 10-04-2016,

Acceptance 15-04-2016, Published 02-05-2016.

Corresponding Author:

Parul,

Department of Anatomy,

Maharaja Agrasen Medical College,

Agroha, Hisar,

Haryana.

E-mail: drparulkalra01@gmail.com

DOI: $10.14260 /$ jemds/2016/484
Subjects were the consenting attendant of patients attending the outpatient department of the Hospital. Individuals with apparent physical deformity and growth and developmental defects were excluded from the study. The aims and objectives of the study and the procedures of examination were explained to the subjects in their own language and a written consent was obtained from them in predesigned and approved format. All measurements were taken after exposure of the relevant body parts in a separate room to maintain the dignity of the individual, in presence of male/female attendant, as the case may be. Stature was measured using anthropometer rod (Minimum count $1 \mathrm{~mm}$ ) while trans-tubercular breadth was measured using round tipped spreading calliper (Minimum count $0.5 \mathrm{~mm}$ ). The collected data was recorded and statistically analysed using "SPSS software version 20.0".

\section{MEASUREMENTS}

- $\quad$ Stature was measured by making the subject to stand bare footed on a horizontal platform in erect posture, keeping the head in Frankfort horizontal plane.[7] It was measured as a vertical distance from the vertex of subject to the floor on which subject is standing. Movable horizontal piece of the anthropometer rod was brought in contact with the vertex in the mid sagittal plane and stature was recorded.

- $\quad$ TTB was measured by making the subject to stand erect after exposure of relevant body part and iliac tubercles on both sides were felt and marked on body surface with the help of a skin marking pencil. Measurement was taken by placing the round tipped spreading calliper on the marked points by standing in front of the subject. 
OBSERVATIONS AND RESULTS

\begin{tabular}{|c|c|c|c|c|c|c|c|c|}
\hline \multirow{2}{*}{ Sex } & \multicolumn{3}{|c|}{ Stature (mm) } & \multicolumn{4}{c|}{ TTB (mm) } \\
\cline { 2 - 9 } & Range & Mean & $\mathbf{\pm}$ SD & SE & Range & Mean & \pm SD & SE \\
\hline Total (Male and Female) & $1400-1840$ & 1598.53 & 95.76 & 5.52 & $240-330$ & 258.14 & 24.49 & 1.41 \\
\hline Male & $1480-1840$ & 1668 & 67.83 & 5.53 & $210-330$ & 265.46 & 23.59 & 1.92 \\
\hline Female Table 1: Showing Range, Mean, SD, Se of Stature and TTB in Male and Female & \multicolumn{5}{c}{23.21} & 1.89 \\
\hline
\end{tabular}

To estimate stature from TTB, regression equations were derived from linear regression analysis in males and females separately as well as together. [Table 2]

$\mathrm{Y}=\mathrm{x} \times \mathrm{b}+\mathrm{c}(\mathrm{Y}=$ Stature, $\mathrm{x}=\mathrm{TTB}, \mathrm{b}=$ Regression coefficient, $\mathrm{c}=$ Constant $)$

\begin{tabular}{|c|c|c|c|}
\hline & Regression Equations & Correlation Coefficient 'r' & 95\% Confidence Interval \\
\hline Males \& Females together & Stature =TTB $\times 1.602+1184.91$ & 0.41 & $1.196-2.009$ \\
\hline Males & Stature=TTB $\times 0.901+1428.740$ & 0.31 & $0.458-1.345$ \\
\hline Females & Stature = TTB $\times 0.748+1341.455$ & 0.27 & $0.318-1.178$ \\
\hline \multicolumn{2}{|c|}{ Table 2: Showing Regression Equations, Correlation Coefficient and 95\% Confidence } \\
Interval for Stature Estimation from TTB in Male and Female
\end{tabular}

Statistically significant correlation was observed between stature and TTB in both sexes. Correlation between stature and TTB in males and females were 0.31 and 0.27 respectively. But in males and females together, correlation was 0.41 . (Scatter plot 1, 2 and 3)

\section{Scatter Plot 1 Showing Correlation of Stature with TTB in} Males

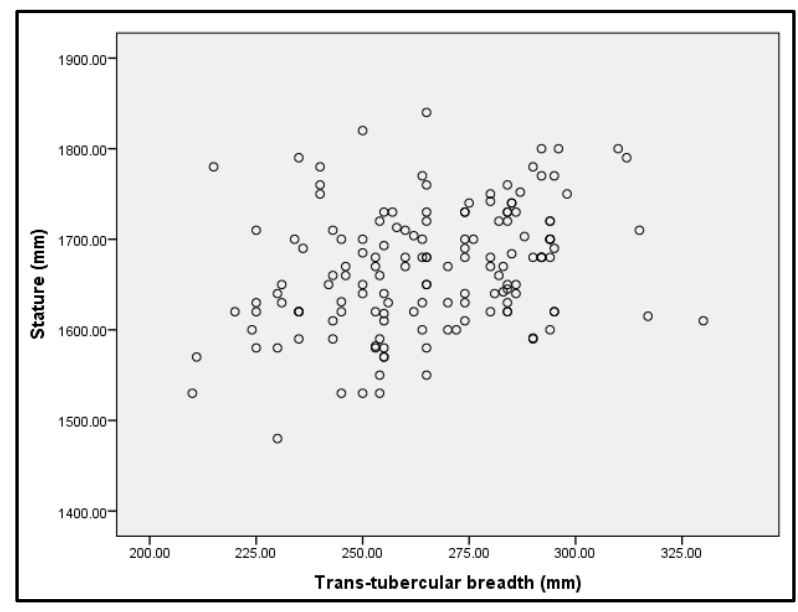

Scatter Plot 2 Showing Correlation of TTB in Females

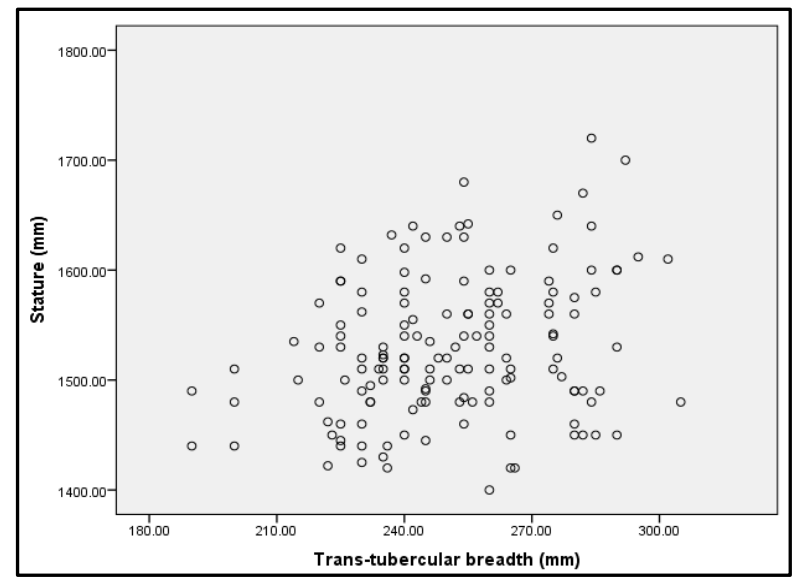

Scatter Plot 3 Showing Correlation of Stature with TTB in both Males and Females

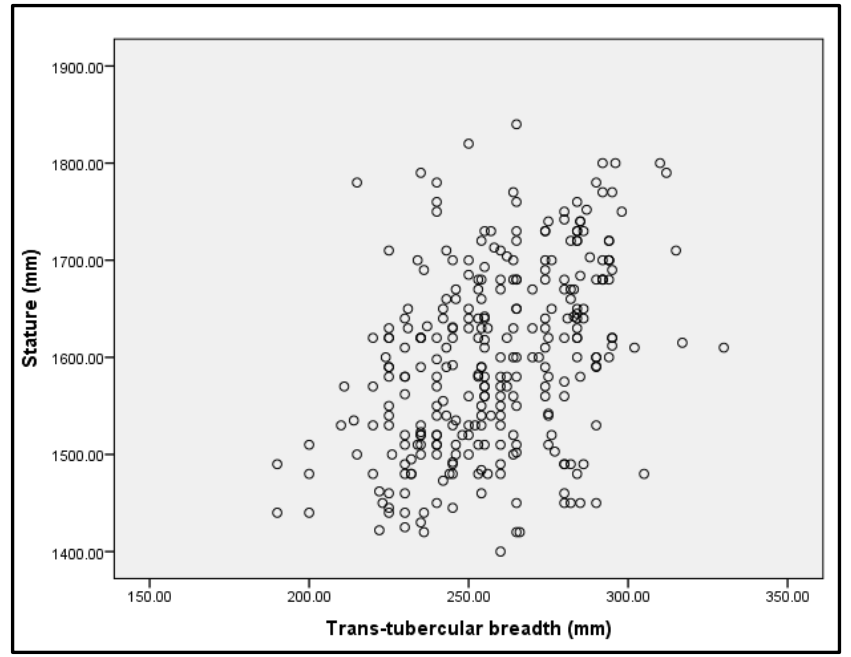

\section{DISCUSSION}

TTB is rarely used as a tool to estimate stature. After a thorough search of literature, it was found that Ozaslan et al did a similar type of study. In his study, stature was measured from TTB on Turkish population. Mean stature and mean TTB of present study is less than that of by Ozaslan et al [Table 3]. The reason may be well built and tall statured Turkish population as compared to Indo-Aryans.[8] The correlation coefficient (r) of stature with TTB of present study for males and females are more than study of Ozaslan et al [Table 3].

\begin{tabular}{|c|c|c|c|c|c|}
\hline $\begin{array}{c}\text { Name } \\
\text { of } \\
\text { Researchers }\end{array}$ & $\begin{array}{c}\text { Geographical } \\
\text { Area } \\
\text { of Study }\end{array}$ & Sex & $\begin{array}{c}\text { Mean of } \\
\text { Stature } \\
\text { (mm) }\end{array}$ & $\begin{array}{c}\text { Mean of } \\
\text { TTB } \\
\mathbf{( m m )}\end{array}$ & $\begin{array}{c}\text { Correlation } \\
\text { Coefficient } \\
\text { 'r' of } \\
\text { Stature } \\
\text { with TTB }\end{array}$ \\
\hline $\begin{array}{c}\text { Ozaslan } \\
\text { et al }\end{array}$ & Turkey & $\mathrm{M}$ & 1724.3 & 288.92 & 0.21 \\
\cline { 3 - 6 } & $\mathrm{F}$ & 1618.6 & 273.31 & 0.19 \\
\hline $\begin{array}{c}\text { Present } \\
\text { study }\end{array}$ & India & $\mathrm{M}$ & 1668 & 265.46 & 0.31 \\
\cline { 3 - 6 } & $\mathrm{F}$ & 1529 & 250.82 & 0.27 \\
\hline
\end{tabular}

Table 3: Showing Comparison of Mean of Stature, TTB and Correlation Coefficients of Present Study with that of Ozaslan et al.

Stature has been estimated from different long bones and various body parts by different workers. Value of correlation coefficients " $r$ " for stature estimation from long 
bones ranged from 0.56-0.76. [9-12] $^{-1}$ from hand length [0.50-0.70] and hand breadth $0.30-0.70 .[13-15]$ from foot length [0.72-0.95] \& foot breadth 0.66-0.76.[16-19] and from arm span ranged from 0.89-0.90.[20] Besides these, other dimensions like cranial length and cranial breadth have also been used for stature estimation with correlation coefficient " $r$ " value ranging from $0.28-0.71$.[21] The best correlation coefficient was observed in the study done by Charnalia et al ( $\mathrm{r}=0.95)$ using foot length. ${ }^{[18]}$ as a tool for stature estimation in male while in females the highest correlation was observed by Supare et al ( $\mathrm{r}=0.90)$ using arm span.[20] as a tool for stature estimation. The correlation coefficient with long bones is highest with ulna $(r=0.76)$ [9] in males and clavicle ( $r=0.68) .{ }^{[9]}$ in females. In the present study correlation coefficient in both males and females ( $r=0.31$ and $r=0.27$ ) are less than all these mentioned studies.

\section{CONCLUSION}

The present study used TTB to measure the stature. However, many better tools are available to measure the stature from different body parts or bones but this study provides an additional tool of stature estimation particularly in absence of other measures.

\section{LIMITATIONS}

Small sample size, covering a small part of India (Northern).

\section{ACKNOWLEDGMENT}

I want to thank Mr. Suryamani Pandey, Assitant Professor, Department of Community Medicine for his statistical help.

\section{REFERENCES}

1. Krishan K. Estimation of stature from footprint and foot outline dimensions in gujjars of North India. Forensic Sci Int 2008;175(2-3):93-101.

2. Jasuja OP, Singh G. Estimation of stature from hand and phalange length. J Indian Acad Forensic Med 2004;26(3):100-6.

3. Ilayperuma I, Nanayakkara G, Palahepitiya N. A model for the estimation of personal stature from the length of forearm. Int J Morphol 2010;28(4):1081-6.

4. Chikhalkar BG, Mangaonkar AA, Nanandkar SD, et al. Estimation of stature from measurements of long bones, hand and foot dimensions. J Indian Acad Forensic Med 2010;32(4):329-31.

5. Ozaslan A, Karadayi B, Kolusayin MO, et al. Stature estimation from bi-acromial and bi-iliocristal measurements. Rom J Leg Med 2011;19(3):171-6.

6. Stranding S. Gray's Anatomy- The anatomical basis of clinical practice. Edinburgh: Churchill Livingstone; 2008; 40 th ed:p 1355.
7. Singh SP, Mehta P. Human body measurements: concepts and application. New Delhi: PHI learning Private Limited 2009.

8. Goutam. Anthropological definitions and classifications of the population in India. available from: http://www.shareyouressays.com/104609/anthropolo gical-definitions-and-classifications-of-population-inindiaexplained accessed on $15 \mathrm{dec}, 2015$.

9. Jit I, Singh S. Estimation of stature from clavicles. Indian J Med Res 1956;44(1):137-55.

10. Pal DC, Datta AK. Estimation of stature from radius length in living adult bengali. Indian Journal of Basic and Applied Medical Research 2014;3(2):380-9.

11. Kate BR, Mazumdar RD. Stature estimation from femur and humerus by regression and autometry. Acta Anat 1976;94(2):311-20.

12. Mahakkanukrauh $P$, Khanpetch $P$, Prasitwattanseree S, et al. Stature estimation from long bone lengths in a thai population. Forensic Sci Int 2011;210(1-3):279.e1-7.

13. Kumar S, Srivastava AK, Sahai MK. Estimation of stature by anthropometric examination of forearm and hand. J Indian Acad Forensic Med 32(1):62-5.

14. Patel JP, Patel BG, Shah RK, et al. Estimation of stature from hand length in Gujarat region. NHL Journal of Medical Sciences 2014;3(1):41-4.

15. Sunil, Dikshit PC, Aggarawal A, et al. Estimation of stature from hand length. J Indian Acad Forensic Med 2005;27(4):219-21.

16. Ozaslan A, Karadayi B, Kolusayin MO, et al. Predictive role of hand and foot dimensions in stature estimation. Rom J Leg Med 2012;20(1):41-6.

17. Khan HM, Moorthy TN. Stature estimation from the anthropometric measurements of foot outline in adult indigenous melanau ethnics of east malaysia by regression analysis. Sri Lanka Journal of Forensic Medicine, Science and Law 2013;4(2):27-34.

18. Charnalia VM. Anthroplogical study of foot and its relationship to stature in different castes and tribes of Pondicherry state. J Anat Soc of India 1961;10:26-30.

19. Patel PN, Tanna JA, Kalele SD. Correlation between hand length and various anthropometric parameters. International journal of Medical Toxicology and Forensic Medicine 2012;2(2):61-3.

20. Suapre MS, Bagul AS, Pandit SV, et al. Estimation of stature from arm span in medical students of Maharashtra, India. Annals of Medical \& Health Sciences Research 2015;5(3):218-21.

21. Ilayperuma I. On the prediction of personal stature from cranial dimensions. Int J Morphol 2010;28(4):1135-40. 